\title{
Use of Task-Based Activities in the Teaching of Drama
}

\author{
Shilpagauri Prasad Ganpule \\ Prof. Ramkrishna More Arts, Commerce and Science College, Akurdi, Pune-411044,University of Pune \\ *Corresponding Author: shilpagauriganpule@gmail.com
}

Copyright (C) 2014 Horizon Research Publishing All rights reserved.

\begin{abstract}
Drama, as a genre of literature, is often considered to be an interesting area in teaching and learning situations. Many methods and techniques are used while teaching drama in an ESL classroom. It is observed that the use of task-based activities proves to be effective and beneficial in the teaching of drama. The present paper strives to focus on the pivotal role of the task-based activities in the teaching and understanding of drama. The paper presents the varied task-based activities that can be used while teaching Oscar Wilde's The Importance of Being Earnest [1] at the undergraduate level. The task-based activities help the students to comprehend the text in a better way. . In fact students' active involvement and participation in the task-based activities not only enhance their understanding of drama but also help them to unravel the plethora of complex meanings woven in the dramatic text. Through the involvement of the students in the task-based activities they learn to infer, interrogate, and interpret the dramatic text. They make guesses, deduce and derive meanings and through inference and reasoning strive to discover the dramatic text. Thus the present paper makes an attempt to prove that the use of the task-based activities in the teaching of drama not only brings in enjoyment but also enhances the students' understanding of the dramatic text.
\end{abstract}

Keywords Teaching of Drama, Task-Based Activities, Students' Participation

\section{Introduction}

The paper discusses the significant role of the task-based activities in the teaching of drama.

The varied task-based activities presume students' participation in the teaching-learning situations. The task-based activities prove to be effective with the students' wholehearted participation. The involvement of students in the task-based activities definitely enhances their understanding of drama. In the present study the text selected is Oscar Wilde's The Importance of Being Earnest [1]. The paper presents the varied task-based activities that can be used while teaching the play at the undergraduate level. It strives to prove that the use of the task-based activities augments the students' appreciation of drama. The present study states that the role of the teacher is that of a catalyst who presents the task-based activities to the students and initiates their process of learning. The teacher facilitates the students and encourages them to engage in the task-based activities. The involvement and engagement of the students in the task-based activities enriches their appreciation of the play. In brief, the task-based activities play a key role in the teaching of drama. The active participation of the students in the varied task-based activities definitely increases their understanding of the play.

\section{The Teaching of Drama}

It is observed that the teaching of drama in an ESL classroom proves to be beneficial to the students in mastering the target language. The teaching of drama not only involves comprehending its content but also the language associated with that content (Aslam, [2]).

The study of the dialogue in drama offers students with "a meaningful context for acquiring and memorizing new language" (Lazar [3]). Drama provides students opportunities for improving their communication skills in authentic and dynamic situations and improves their confidence to master the target language (Boudreault[4]). Drama helps "students gain greater insights into conversational language" (Lazar [3]). Drama offers an excellent platform for exploring theoretical and practical aspects of the English language (Whiteson [5]). The recreation aspect of drama is very important and when the students are having fun, they let their second language guard down and become less inhibited (Boudreault, 2010). Through the teaching of drama the students "...learn to express themselves; add new words to their vocabulary and develop confidence" (Jain and Sharma [6]). Drama has the written text and performance text. The two distinctive features of the play are: it exists in performance and also exists as words on a page or text (Lazar [3]). The play has many meanings in performance and gestures, movement costumes, sets etc. are also to be taken into consideration. Drama is not made of only words, but of sights and sounds, stillness and motion, noise and silence, relationships and responses (Styan [7]). Hence, the teacher should always take into consideration the performance aspect of the play (Lazar [3]). Different techniques are used by teachers for the effective teaching of drama. 


\subsection{Students' Participation in the Task-based Activities}

In the teaching of drama the teacher can use different task-based activities to make the teaching-learning situation fruitful and rewarding. The participation of the students in the task-based activities is very crucial in the teaching learning situation. In fact, the teaching of drama helps shift the centre from the teacher to the students (Maley [8]). Due to the active participation of the students in the task-based activities there is a shift from the teacher-centred class to the student-centred class. The students partake in the varied task-based activities and give their valuable input so as to understand the play in a better way. The teacher can motivate the students; can inspire them to give their contribution to the given tasks, but unless and until the students do not involve themselves in the task-based activities; they cannot comprehend the play. "...total involvement on the part of the learner can be guaranteed only if he/she is motivated and interested in the activity" (Kudchedkar [9]). In brief, true involvement on the part of the students is very important in the understanding of drama. Thus the students certainly play a significant role in the teaching of drama.

\section{The Case Study: The Teaching of Oscar Wilde's_The Importance of Being Earnest (1994)}

The play chosen for the present study is The Importance of Being Earnest by Oscar Wilde [1]. It is observed that the students find it interesting. It is a comedy of manners full of wit, fun and wondrous events. The theme of love is universal and appealing to the students. Due to the complexities in the plot structure and the element of mystery the play becomes absorbing and exciting to the students. They get engrossed in the play and find it amusing and entertaining. The mystery of Jack Worthing's birth and the name "Ernest" in the play excite the curiosity of the students and the unraveling of the identity of the protagonist Jack in the end engage the interest of the students till the curtain falls down.

\subsection{Use of the Task-based Activities in the Teaching of The Importance of Being Earnest}

The Teaching of The Importance of Being Earnest [1] in the ESL classroom through the task-based activities makes the teaching-learning situation pleasurable and rewardful. The students generally have difficulty to work in the foreign language and to combine the simultaneous demands of comprehension and language production (Coolie and Slater [10]). But it is observed that the task-based activities make the students, understand the setting of the play, familiarize with the characters, know the scenes, unravel its plot-structure and in brief, comprehend the play in an improved manner. They "stimulate interest and help learners overcome the barriers posed by language" (Coolie and Slater [10]). They successfully overcome the problem of L2 comprehension and grasp the theme, story line and plot-structure of the play. The activities foster a strong sense of involvement on the part of the students and encourage them to learn through active participation (Lazar [3]). Thus, the task-based activities induce the students to perform diverse tasks and accelerate their learning process. Language is learnt effectively when the students are made to do things by themselves (Kudchedkar [9]). The task-based activities make the students do things on their own.

While designing the task-based activities for the teaching of drama, an attempt is made to integrate the language skills, listening, speaking, reading and writing. There is not just a single skill, but a combination of different skills at the same time is done. Listening skill is integrated with reading, writing or speaking skill. As the task-based activities are learner-centred, they make the students deploy their cognitive sub-skills, they make the students predict, anticipate, guess from the context, use their previous experience, etc. (Kudchedkar [9]).

The task-based activities that can be actually used while teaching Oscar Wilde's [1] The Importance of Being Earnest are given. (Refer to Appendix I)

\subsubsection{See the PowerPoint Presentation and Jot down the Important Facts of Oscar Wilde's life and his works.}

In this activity the students are asked to watch the PowerPoint Presentation and write down the important happenings from Oscar Wilde's life. They are also asked to enlist Wilde's literary works. This activity enhances the students' reading and writing skills. It introduces the students with the life and works of Oscar Wilde. The visual appeal of the PowerPoint Presentation with the photographs of Wilde and the pictures of the title pages of the works makes the teaching-learning situation lively and casts an everlasting impression on the students.

\subsection{2 . See the PowerPoint Presentation and Enlist the Characters of the Play.}

In this activity the students are presented with the PowerPoint Presentation in which the different characters of the play are presented along with a brief introduction of them. The intention behind this activity is to familiarize the students with the characters of the play.

\subsubsection{Fill in the Sociogram Given Below.}

This activity gives the students clarity about the relationship amongst the different characters of the play. It presents the main characters and their relationships to each other. It also indirectly makes them think about the plot of the play. Figure 1 displays a sociogram based on the play. 


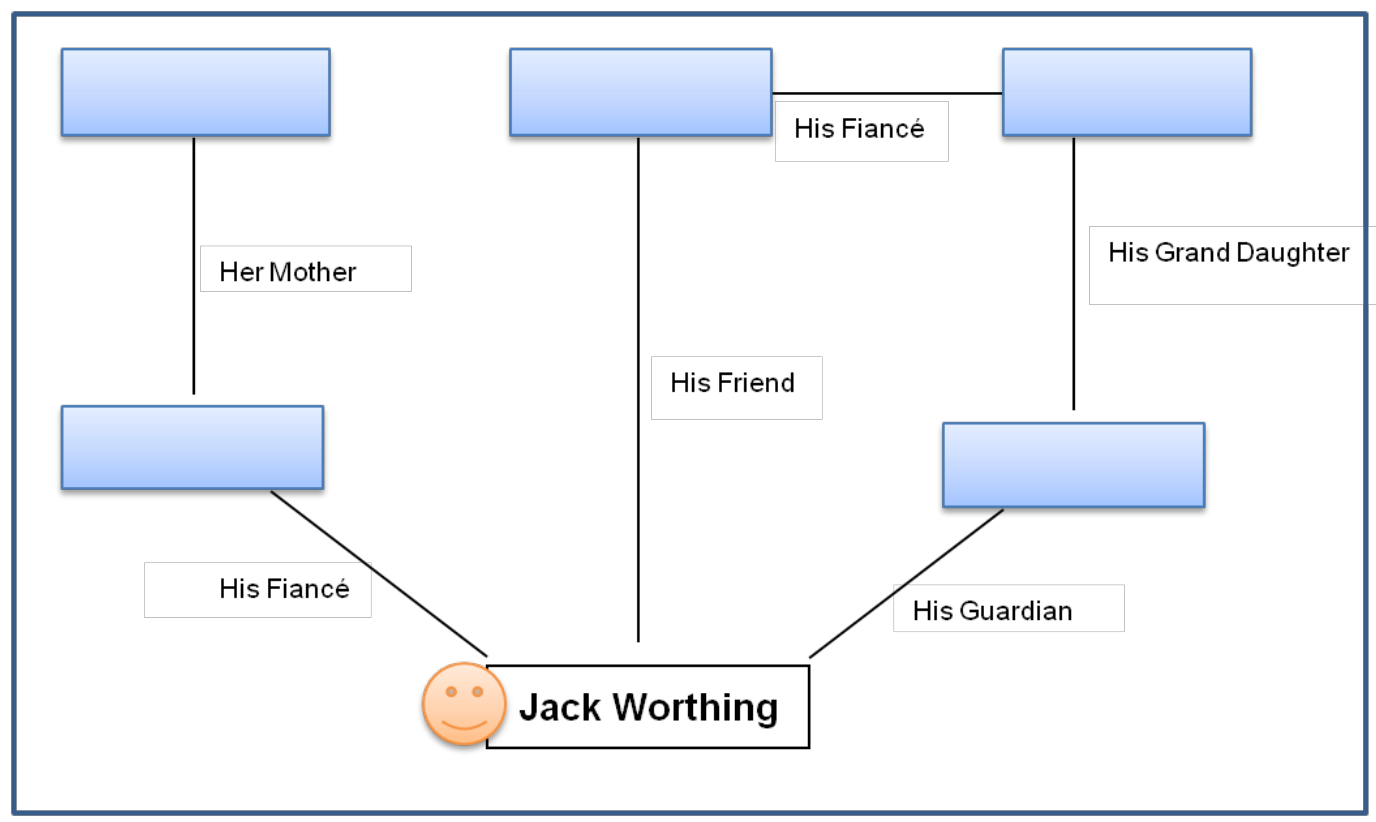

Figure 1. Sociogram of The Importance of Being Earnest

\subsubsection{Assigning Roles to Different Students and Making Them Read the Text}

The act wise reading of the text is followed by a discussion amongst the students regarding the characterization, setting and plot of the play. In this activity the students are encouraged to participate in the discussion followed by the reading of the different acts. This activity helps the students to acquaint with the characters, to know the setting, to apprehend the storyline and to comprehend the happenings in the plot structure. It also improves the students' reading, listening and speaking skills. It enables the students to read written English correctly. It enables them to use appropriate sounds, juncture, stress and intonation patterns in reading English. It enables them to guess the meaning of unfamiliar words and phrases in the context. It enables the students to understand the lexical and structural meanings of the words, phrases and sentences. It helps the students recognize the meaning of various graphic signals that is, punctuation mark, paragraph indentation, capitalization, etc.

\subsubsection{Screening Act Wise the Video Clips of the Play}

After the oral reading of each act of the play the video clip of the act is screened. The screening is followed by a discussion. This activity improves the students' listening and speaking skills. It also develops the students' cognitive skill. It also supports the students' understanding of the play. It develops the students' critical thinking. The audio-visual aid improves the students' appreciation of the play.

\subsubsection{Rewrite the following sentences in paragraph form, in the correct sequence (Collie and Slater [10]).}

In this activity the students are given jumbled sentences. They are asked to rearrange and rewrite the sentences to form a meaningful paragraph. This activity helps the students to understand the chronology of events that happen in the play.

\section{Worksheet 1 \\ Rewrite the following sentences in paragraph form, in the correct sequence.}

a) Algernon secretly listens to the conversation between Gwendolen and Jack Worthing and writes Jack's address on his shirt cuff.

b) Algernon asks Jack to disclose the mystery of Jack's relationship with Cecily.

c) Jack tells Algernon that he has created a younger brother named "Ernest" in order to visit London for pleasure.

d) Lady Bracknell tells Jack that she would not permit her daughter to marry a railway parcel.

e) Algernon informs Jack that his aunt Lady Bracknell and Gwendolen are expected to arrive to tea.

f) Jack admits that he has two names: Ernest Worthing in the city and Jack Worthing in the country.

g) Jack Worthing expresses his love for Gwendolen and proposes to her.

h) Lady Bracknell warns Jack that she would allow her daughter to marry Jack only if Jack can find out the identity of at least one of his parents.

i) Algernon confesses that he has created an imaginary character "Bunbury" to facilitate him to visit different places for pleasure.

j) Jack explains Algernon that late Mr. Thomas Cardew adopted him as a boy and appointed him as a guardian of his grand-daughter Cecily.

k) Jack reveals the secret of his birth to Lady Bracknell. He tells her that he was found in a hand-bag in the cloak room at Victoria Railway Station.

\section{Worksheet 2}

Rewrite the following sentences in paragraph form, in the correct sequence.

a) Jack informs Dr. Chasuble and Miss Prism about the death of his younger brother Ernest. 
b) Cecily tells Algernon alias Ernest that she is engaged to him ever since she had come to know about him from Uncle Jack.

c) Jack is shocked to see Algernon in his house as his brother and warns him to leave his house immediately.

d) Algernon decides to go to Dr. Chasuble for rechristening.

e) Cecily and Gwendolen fight with each other as they think that they both are engaged with the same person whose name is "Ernest".

f) Miss Prism goes along with Dr. Chasuble for a walk.

g) Cecily tells Gwendolen that Algernon is "Ernest".

h) Cecily states that she loves Algernon as his name is "Ernest".

i) Cecily informs Uncle Jack about the arrival of his younger brother "Ernest".

j) Algernon tells Cecily that he is Jack's younger brother "Ernest".

k) Gwendolen tells Cecily that Uncle Jack is "Ernest".

l) Cecily is studying German along with Miss Prism.

m) The conflict between Gwendolen and Cecily is resolved when Gwendolen introduces Jack and Cecily announces Algernon to be "Ernest".

\section{Worksheet 3}

Rewrite the following sentences in paragraph form, in the correct sequence.

a) Lady Bracknell arrives in Manor House and objects Gwendolen's marriage to Jack Worthing.

b) Lady Bracknell tells Jack that he was given the name of his father, a general in the British Army..

c) Miss Prism declares that she is unmarried.

d) Jack warns Lady Bracknell that he would allow his ward Cecily to marry to Algernon only if she allows Jack to marry Gwendolen.

e) Lady Bracknell recognizes Miss Prism and asks her the whereabouts of her lost nephew.

f) Lady Bracknell declares that Jack Worthing is the elder son of her sister and Algernon is his younger brother.

g) Jack mistakenly considers Miss Prism to be his mother and embraces her thinking her to be his mother.

h) Jack embraces Gwendolen, Algernon hugs Cecily and Dr. Chasuble embraces Miss Prism.

i) Dr. Chasuble comes and tells about the arrangements he has made for the christening ceremony.

j) Jack searches in the Army lists and finds his father's name to be "Ernest".

k) Lady Bracknell gives her consent to Algernon to marry to Cecily when she comes to know about Cecily's fortune.

1) Jack brings the hand-bag and Miss Prism recognizes it immediately.

m) Cecily and Gwendolen forgive Algernon and Jack.

n) Miss Prism confesses that she kept the baby in the hand-bag and placed the manuscript of her novel in the perambulator.

3.2.7. Guess what would have happened, if...? a) What would have happened if Miss Prism would not have disclosed the secret of the hand-bag?

b) What would have happened if Algernon would not have secretly written Jack's address of the Manor House?

c) What would have happened if Lady Bracknell would have considered the alliance of Gwendolen with Jack Worthing?

In this activity the students are divided into groups and each group is given an improbable situation and is asked to think about the probability of the situation. This activity helps the students to think independently about the given situation. It also helps them to develop their speaking skills as they discuss things amongst themselves. It helps the students to deploy their cognitive sub-skills such as predicting, anticipating, guessing from the context, using the previous experience etc.

\subsubsection{Find out the epigrams used in the play and write them} in your notebooks.

The teacher explains the students the term "epigram" and makes three groups of students. Each group is assigned one act and is asked to read aloud the act and write down the epigrams. In this activity the students read aloud the act and do scanning of the act and then write down the epigrams. This activity enhances the students' reading skills. It facilitates them to study and scrutinize the use of language in the play.

\subsubsection{The students are divided into small groups and are asked to have a group discussion on the following epigrams used in the play.}

The activity encourages the students to think logically and to speak out their ideas systematically in a group. It also helps them develop their speaking skills. It is observed that the students enjoy this activity and present their thoughts in the framework of their own cultural contexts.

a) "The very essence of romance is uncertainty" (Pg. 5).

b) "...the girls never marry the men they flirt with" (Pg. 6).

c) "...in married life three is company and two is none" (Pg. 6).

d) "The good ended happily, and the bad unhappily. That is what fiction means" (Pg. 27).

e) “...by persistently remaining single a man converts himself into a permanent public temptation” (Pg. 32).

3.2.10. Fill in the grid in Figure 2 with brief remarks.

\begin{tabular}{|c|c|l|c|l|}
\hline Setting & Temporal & & Genre & \\
\hline & Geographical & & & \\
\hline & Physical & & Tone & \\
\hline Plot & $\begin{array}{c}\text { Rising } \\
\text { Action }\end{array}$ & & Theme & \\
\hline & Climax & & & \\
\hline & Falling & & Major & \\
& Action & & Conflict & \\
\hline
\end{tabular}

Figure 2. Grid

In this activity the students are asked to fill in the grid. 
This activity helps the students to revise the facts that they have already known. It helps them to enhance their writing skill. It helps them to organize the thoughts and ideas logically.

\subsubsection{Prepare a poster on:}
a) The setting of the play
b) The plot of the play
c) Life and works of Oscar Wilde

In this activity the students are divided into groups and are asked to prepare a poster on the given topics. This activity enhances the students' imaginative power. It appeals to the creativity of the students and also helps them in understanding the play.

\subsubsection{Make a list of comic episodes in the play and discuss} the comic element in each of the episode.

In this activity the students are divided into three groups and are assigned with one act each. They are asked to scan the act and enlist the comic episodes. This activity enhances the students' reading and speaking skills. It also helps them to understand the comic element in the play.

\subsubsection{Write a letter on the topics given below.}

\section{a) Cecily's love letter to Ernest}

b) Gwendolen's love letter to Ernest

c) Thomas Cardew's letter to Jack before his death

In this activity the students are asked to imagine themselves as characters and write a letter from the point of view of the given characters. This activity enhances the students' writing skills and cognitive skills. This activity appeals to the students' imaginative power and make them envisage the point of view of the characters. The students like this activity very much. They predict, anticipate and use their previous knowledge to write the letter. It enables the students to use proper punctuation marks in writing the letter and to use words appropriately.

\subsubsection{Read the passage and answer the questions given below:}

In this activity the students are asked to think and write the answers of the given questions. This activity encourages the students to write answers on their own. It checks the students' comprehension of the passage and also helps them to develop their writing skills. The answers are discussed in the class and the students are given the feedback on the assessed answer books.

\section{Passage 1}

Jack: You really love me, Gwendolen?

Gwendolen: Passionately!

Jack: Darling you don't know how happy you've made me.

Gwendolen: My own Ernest!

Jack: But you don't really mean to say that you couldn't love me if my name wasn't Ernest.

Gwendolen: But your name is Ernest.

Jack: Yes, I know it is. But supposing it was something else? Do you mean to say you couldn't love me then?
Gwendolen: Ah! That is clearly a metaphysical speculation has very little reference at all to the actual facts of real life, as we know them.

Jack: Personally, darling, to speak quite candidly, I don't much care about the name of Ernest......I don't think the name suits me at all.

Gwendolen: It suits you perfectly, it is a divine name. It has music of its own. It produces vibration.

Jack: Well, really, Gwendolen, I must say that I think there are lots of other much nicer names. I think Jack, for instance, a charming name (Pg.114).

\section{Questions:}

1. What is the significance of the passage in plot of the play?

2. How is the name 'Ernest' crucial to the love relation between Jack and Gwendolen?

3. Why did Gwendolen love Jack?

4. Comment on the use of language in the passage.

5. Which is the epigram used in the passage?

\section{Passage 2}

Lady Bracknell: Oh, they count as Tories. They dine with us or come in the evening, at any rate. Now to minor matters. Are your parents living?

Jack: I have lost both my parents.

Lady Bracknell: To lose one parent, Mr. Worthing, may be regarded as a misfortune; to lose both looks like carelessness. Who was your father? He was evidently a man of some wealth. Was he born in what the Radical papers call the purple of commerce, or did he rise from the ranks of the aristocracy?

Jack: I am afraid I really don't know. The fact is, Lady Bracknell, I said I had lost my parents. It would be nearer the truth to say that my parents seem to have lost me...I don't actually know who I am by birth. I was... well, I was found.

Lady Bracknell: Found!

Jack: The late Mr. Thomas Cardew, an old gentleman of a very charitable and kindly disposition, found me, and gave me the name of Worthing, because he happened to have first-class ticket for Worthing in his pocket at the time. Worthing is a place in Sussex. It is a seaside resort. Lady Bracknell: Where did the charitable gentleman who had a first-class ticket for this seaside resort find you? Jack: In a handbag. Lady Bracknell: A handbag?

Jack: Yes, Lady Bracknell. I was in a hand- bag- a somewhat large, black leather handbag, with handles to itan ordinary handbag in fact.

Lady Bracknell: In what locality did this Mr. James or Thomas Cardew come across this ordinary handbag? Jack: In the cloakroom at Victoria Station. It was given to him in mistake for his own.

\section{Questions:}

1. Comment on the matrimonial system in England.

2. What was the secret of Jack's birth?

3. Where was Jack found?

4. Comment on the character of Lady Bracknell.

5. What is the significance of the passage in plot of the play? 
3.2.15. Watch the movie and write a review of the film $\underline{\text { The }}$ Importance of Being Earnest in the light of the following points:
a) Setting
b) Music
c) Props
d) Gestures
e) Costumes

In this activity the film is screened and then the students are asked to write a review of the film in the light of the given points. This activity facilitates the students to improve their writing skills. It also assists them to analyze the play as a whole.

\subsubsection{Choose a role card and give a performance. The} situations written on the role cards are given below.

a) Jack Worthing proposing Gwendolen

b) Algernon flirting with Cecily in the Manor House

c) Gwendolen and Cecily fighting with each other for having "Ernest" as their lover

d) Miss Prism's encounter with Lady Bracknell

e) Cecily in Miss Prism's class in the garden

f) Lady Bracknell's interview of Jack Worthing as a prospective husband of her daughter

g) Jack' announcement of his brother's death challenged by Cecily

In this activity a pair or group of students are asked to choose a role card and give a performance on the situation mentioned on the card. In this activity the students are given practice in oral communication. This activity builds their confidence, minimizes their stage fright and makes them use language in different situations. This activity also enhances their understanding of the play. The students enjoy this activity.

\subsection{Level of Difficulty of the Task-based Activities}

The level of difficulty of the task-based activities differs from question to question. It is in the range of easy, moderate and difficult. The easy and moderate level task-based activities focus on the factual information which is provided to the students. In case of the difficult level task-based questions the students have to use their imaginative power and creativity. They have to use their cognitive sub-skills. They have to think on their own and then solve the questions or engage in activities. (Refer to Appendix II)

\section{Conclusions}

Thus the paper makes an attempt to provide taxonomy of variety of task-based activities that can be used for the teaching of The Importance of Being Earnest (1994) at the undergraduate level. It states that the students' active participation in the task-based activities enhance their understanding of drama. While designing the task-based activities for the teaching of drama, an attempt is made to integrate the language skills, listening, speaking, reading and writing. The students are also encouraged to use the cognitive sub-skills. Thus, the paper proves that the task-based activities play a significant role in the teaching of drama.

\section{APPENDICES}

I. List of Task-based Activities that can be Used in the Teaching of The Importance of Being Earnest (1994)

\begin{tabular}{|c|c|c|c|c|}
\hline Sr. No. & Task-based Activity & $\begin{array}{c}\text { Development of } \\
\text { Skills } \\
\end{array}$ & $\begin{array}{c}\text { Development of } \\
\text { Sub-skills }\end{array}$ & Other Benefits \\
\hline 3.2 .1 & $\begin{array}{l}\text { See the PowerPoint } \\
\text { Presentation and jot } \\
\text { down the important } \\
\text { facts of Oscar Wilde's } \\
\text { life. Jot down the works } \\
\text { of Oscar Wilde. }\end{array}$ & $\begin{array}{l}\text { Reading and } \\
\text { writing skills }\end{array}$ & $\begin{array}{l}\text { Skimming, } \\
\text { scanning, } \\
\text { note-taking }\end{array}$ & $\begin{array}{l}\text { introduces the } \\
\text { students with the } \\
\text { life and works of } \\
\text { Oscar Wilde }\end{array}$ \\
\hline 3.2 .2 & $\begin{array}{l}\text { See the PowerPoint } \\
\text { Presentation and enlist } \\
\text { the characters of the } \\
\text { play }\end{array}$ & $\begin{array}{l}\text { Reading and } \\
\text { writing skills }\end{array}$ & $\begin{array}{l}\text { Skimming, } \\
\text { scanning, } \\
\text { note-taking }\end{array}$ & $\begin{array}{l}\text { familiarizes the } \\
\text { students with the } \\
\text { characters of the } \\
\text { play }\end{array}$ \\
\hline 3.2 .3 & Fill in the sociogram & Cognitive skill & $\begin{array}{l}\text { Predicting, } \\
\text { guessing from the } \\
\text { context }\end{array}$ & $\begin{array}{l}\text { presents the main } \\
\text { characters and } \\
\text { their relationships } \\
\text { to each other. }\end{array}$ \\
\hline
\end{tabular}




\begin{tabular}{|c|c|c|c|c|}
\hline Sr. No. & Task-based Activity & $\begin{array}{l}\text { Development of } \\
\text { Skills }\end{array}$ & $\begin{array}{l}\text { Development of } \\
\text { Sub-skills }\end{array}$ & Other Benefits \\
\hline 3.2 .4 & $\begin{array}{l}\text { Assigning roles to } \\
\text { different students and } \\
\text { making them read the } \\
\text { text }\end{array}$ & $\begin{array}{c}\text { Reading, } \\
\text { listening and } \\
\text { speaking skills }\end{array}$ & $\begin{array}{l}\text { Loud reading, } \\
\text { Skimming, } \\
\text { scanning }\end{array}$ & $\begin{array}{l}\text { helps the students } \\
\text { to acquaint with } \\
\text { the characters, to } \\
\text { know the setting, } \\
\text { to apprehend the } \\
\text { storyline and to } \\
\text { comprehend the } \\
\text { happenings in the } \\
\text { plot structure }\end{array}$ \\
\hline 3.2 .5 & $\begin{array}{l}\text { Screening act wise the } \\
\text { video clips of the play } \\
\text { followed by a discussion }\end{array}$ & $\begin{array}{l}\text { Listening skill } \\
\text { speaking skill } \\
\text { Cognitive skill }\end{array}$ & $\begin{array}{l}\text { Comprehending } \\
\text { Pronunciation } \\
\text { Conversation } \\
\text { Predicting } \\
\text { Using the previous } \\
\text { experience } \\
\end{array}$ & $\begin{array}{l}\text { supports the } \\
\text { students' } \\
\text { understanding of } \\
\text { the play. }\end{array}$ \\
\hline 3.2 .6 & $\begin{array}{l}\text { Rewrite the following } \\
\text { sentences in paragraph } \\
\text { form, in the correct } \\
\text { sequence }\end{array}$ & $\begin{array}{l}\text { Reading and } \\
\text { writing skills }\end{array}$ & $\begin{array}{l}\text { Silent reading } \\
\text { Skimming, } \\
\text { scanning } \\
\text { Mechanics of } \\
\text { writing } \\
\text { Organizing } \\
\text { cohesive } \\
\text { paragraphs } \\
\end{array}$ & $\begin{array}{l}\text { helps the students } \\
\text { to understand the } \\
\text { chronology of } \\
\text { events that happen } \\
\text { in the play. }\end{array}$ \\
\hline 3.2 .7 & $\begin{array}{c}\text { Guess what would have } \\
\text { happened, if...? }\end{array}$ & $\begin{array}{l}\text { Speaking skill } \\
\text { Cognitive skill }\end{array}$ & $\begin{array}{l}\text { Pronunciation } \\
\text { Conversation } \\
\text { Predicting, } \\
\text { guessing from the } \\
\text { context }\end{array}$ & $\begin{array}{l}\text { helps the students } \\
\text { to think } \\
\text { independently } \\
\text { about the given } \\
\text { situation }\end{array}$ \\
\hline 3.2 .8 & $\begin{array}{c}\text { Find out the epigrams } \\
\text { used in the play and } \\
\text { write them in your } \\
\text { notebooks. }\end{array}$ & $\begin{array}{l}\text { Reading and } \\
\text { writing skills }\end{array}$ & $\begin{array}{l}\text { Skimming, } \\
\text { scanning, } \\
\text { note-taking }\end{array}$ & $\begin{array}{l}\text { facilitates them to } \\
\text { study and } \\
\text { scrutinize the use } \\
\text { of language in the } \\
\text { play }\end{array}$ \\
\hline 3.2 .9 & $\begin{array}{l}\text { The students are divided } \\
\text { into small groups and } \\
\text { are asked to have a } \\
\text { group discussion on the } \\
\text { epigrams used in the } \\
\text { play. }\end{array}$ & $\begin{array}{l}\text { Speaking skill } \\
\text { Cognitive skill }\end{array}$ & $\begin{array}{l}\text { Pronunciation } \\
\text { Conversation } \\
\text { Intonation }\end{array}$ & $\begin{array}{l}\text { encourages the } \\
\text { students to think } \\
\text { logically and to } \\
\text { speak out their } \\
\text { ideas } \\
\text { systematically in a } \\
\text { group }\end{array}$ \\
\hline 3.2 .10 & $\begin{array}{l}\text { Fill in the grid with brief } \\
\text { remarks. }\end{array}$ & $\begin{array}{l}\text { Writing skill } \\
\text { Cognitive skill }\end{array}$ & $\begin{array}{l}\text { Mechanics of } \\
\text { writing }\end{array}$ & $\begin{array}{l}\text { helps the students } \\
\text { to revise the facts } \\
\text { that they have } \\
\text { already known. }\end{array}$ \\
\hline 3.2 .11 & Prepare a poster & Writing skill & $\begin{array}{l}\text { Mechanics of } \\
\text { writing } \\
\text { Organizing } \\
\text { cohesive } \\
\text { paragraphs }\end{array}$ & $\begin{array}{l}\text { Enhances the } \\
\text { students' } \\
\text { imaginative power } \\
\text { and appeals to } \\
\text { their creativity }\end{array}$ \\
\hline 3.2 .12 & $\begin{array}{l}\text { Make a list of comic } \\
\text { episodes in the play and } \\
\text { discuss the comic } \\
\text { element in each of the } \\
\text { episode }\end{array}$ & $\begin{array}{l}\text { Reading and } \\
\text { speaking skills }\end{array}$ & $\begin{array}{l}\text { Skimming, } \\
\text { scanning } \\
\text { Pronunciation } \\
\text { Conversation }\end{array}$ & $\begin{array}{l}\text { helps them to } \\
\text { understand the } \\
\text { comic element in } \\
\text { the play. }\end{array}$ \\
\hline 3.2 .13 & $\begin{array}{l}\text { Write a letter on the } \\
\text { given topics }\end{array}$ & $\begin{array}{l}\text { Writing skill } \\
\text { Cognitive skill }\end{array}$ & $\begin{array}{l}\text { Mechanics of } \\
\text { writing } \\
\text { Organizing } \\
\text { cohesive } \\
\text { paragraphs } \\
\text { Predicting and } \\
\text { anticipating }\end{array}$ & $\begin{array}{l}\text { appeals to the } \\
\text { students' } \\
\text { imaginative power } \\
\text { and make them } \\
\text { envisage the point } \\
\text { of view of the } \\
\text { characters }\end{array}$ \\
\hline
\end{tabular}




\begin{tabular}{|c|c|c|c|c|}
\hline Sr. No. & Task-based Activity & $\begin{array}{c}\text { Development of } \\
\text { Skills }\end{array}$ & $\begin{array}{l}\text { Development of } \\
\text { Sub-skills }\end{array}$ & Other Benefits \\
\hline 3.2 .14 & $\begin{array}{l}\text { Read the passage and } \\
\text { answer the questions } \\
\text { given below }\end{array}$ & $\begin{array}{l}\text { Reading and } \\
\text { writing skill }\end{array}$ & $\begin{array}{l}\text { Silent reading, } \\
\text { skimming, } \\
\text { scanning }\end{array}$ & $\begin{array}{c}\text { checks the } \\
\text { students' } \\
\text { comprehension of } \\
\text { the passage }\end{array}$ \\
\hline 3.2 .15 & $\begin{array}{l}\text { Watch the movie and } \\
\text { write a review of the } \\
\text { film The Importance of } \\
\underline{\text { Being Earnest }}\end{array}$ & $\begin{array}{l}\text { Listening and } \\
\text { writing skills }\end{array}$ & $\begin{array}{l}\text { Note-taking } \\
\text { Mechanics of } \\
\text { writing } \\
\text { Organizing } \\
\text { cohesive } \\
\text { paragraphs }\end{array}$ & $\begin{array}{c}\text { assists the students } \\
\text { to analyze the play } \\
\text { as a whole }\end{array}$ \\
\hline 3.2 .16 & $\begin{array}{l}\text { Choose a role card and } \\
\text { give a performance }\end{array}$ & $\begin{array}{l}\text { Speaking skill } \\
\text { Cognitive skill }\end{array}$ & $\begin{array}{l}\text { Pronunciation } \\
\text { Conversation } \\
\text { Predicting, } \\
\text { anticipating, } \\
\text { guessing from the } \\
\text { context, using the } \\
\text { previous } \\
\text { experience }\end{array}$ & $\begin{array}{l}\text { builds the } \\
\text { students' } \\
\text { confidence, } \\
\text { minimizes their } \\
\text { stage fright and } \\
\text { makes them use } \\
\text { language in } \\
\text { different } \\
\text { situations. }\end{array}$ \\
\hline
\end{tabular}

\section{Level of Difficulty of the Task-based Activities}

\begin{tabular}{|c|c|c|c|}
\hline \multirow{2}{*}{ Sr. No. } & \multicolumn{3}{|c|}{ Level of Difficulty of the Task-based Activities } \\
\hline & Easy & Moderate & Difficult \\
\hline 3.2 .1 & $\sqrt{ }$ & - & - \\
\hline 3.2 .2 & $\sqrt{ }$ & - & - \\
\hline 3.2 .3 & - & $\sqrt{ }$ & - \\
\hline 3.2 .4 & - & $\sqrt{ }$ & - \\
\hline 3.2 .5 & - & $\sqrt{ }$ & - \\
\hline 3.2 .6 & - & $\sqrt{ }$ & - \\
\hline 3.2 .7 & - & - & $\sqrt{ }$ \\
\hline 3.2 .8 & - & $\sqrt{ }$ & - \\
\hline 3.2 .9 & - & - & $\sqrt{ }$ \\
\hline 3.2 .10 & - & - & $\sqrt{ }$ \\
\hline 3.2 .11 & - & $\sqrt{ }$ & - \\
\hline 3.2 .12 & $\sqrt{ }$ & - & - \\
\hline 3.2 .13 & $\sqrt{ }$ & - & - \\
\hline 3.2 .14 & - & $\sqrt{ }$ & - \\
\hline 3.2 .15 & - & - & $\sqrt{ }$ \\
\hline 3.2 .16 & - & - & $\sqrt{ }$ \\
\hline
\end{tabular}

\section{REFERENCES}

[1] Wilde, O. The Importance of Being Earnest. Madras: Macmillan India Ltd.; 1994.

[2] Aslam, M. Teaching of English A Practical Course for B. Ed.
Students. New Delhi, India: Foundation Books; 2009.

[3] Lazar, G. Literature and Language Teaching. New Delhi: Cambridge University Press; 2009:138.

[4] Boudreault, C. "The Benefits of Using Drama in the ESL/EFL 
Classroom" in The Internet TESL Journal, Vol. XVI, No. 1, January

[5] Whiteson, V. (1996). New Ways of Using Drama and Literature in Language Teaching. Alexandria,VA., TESOL. 2010, Retrieved from http://iteslj.org/Articles/Boudreault-Drama.html

[6] Jain, R.K. and Sharma, C. K. Essentials of English Teaching. Agra, India: Vinod Pustak Mandir; 2006; ISBN 81-7457-280-5: 87.

[7] Styan, J. L. Drama, Stage and Audience. Cambridge: Cambridge University Press; 1975.

[8] Maley, A.and Duff A. Drama Techniques in Language Learning. Cambridge: Cambridge University Press; 1982.

[9] Kudchedkar, S. English Language Teaching in India. Chennai: Orient Longman; 2002: 198.

[10] Coolie, J. and Slater, S. Literature in the Language Classroom. New Delhi: Cambridge University Press; 2009: 163-64.

[11] Yardi, V. Teaching English in India Today. Aurangabad, India: Parimal Prakashan; 1994.

[12] Evans, G.L. The Language of Modern Drama. Dent and Sons;
1977.

[13] Gurav, H.K. Teaching Aspects of English Language. Pune: Nutan Prakashan; 2005.

[14] Holden, Susan. Drama in Language Teaching. Essex: Longman; 1981.

[15] Kocchar, S. Methods and Techniques of Teaching, New Delhi, India: Sterling Publishers Pvt. Ltd.; 2003.

[16] McCaslin, N. Creative Drama in the Classroom and Beyond. London: Longman Publishers; 1996.

[17] Nagraj, G. English Language Teaching Approaches Methods Techniques. Hyderabad, India: Orient Longman; 1996.

[18] Paliwal, A. English Language Teaching, Jaipur, India: Surabhi Publications; 1996.

[19] Parrott, M. Tasks for Language Teachers. New Delhi: Cambridge University Press; 2010.

[20] Raimes, A. "Producing a piece of writing" in Techniques in Teaching Writing. Oxford. Oxford University Press; 1983.

[21] Saraswathi, V. English Language Teaching Principles and Practice. Chennai, India: Orient Longman; 200 